\title{
Prevalence of Head Lice in Two Socio-economically Different Schools in the Center of Izmir City, Turkey
}

\author{
İzmir’de Sosyo-ekonomik Olarak Farklı İki Okulda Baş Biti Yaygınlığının Araştırılması
}

\section{Mehmet Karakuş', Aylin Arıcı², Seray Özensoy Töz³, Yusuf Özbel ${ }^{3}$}

'Department of Biology, Ege University Faculty of Medicine, İzmir, Turkey

${ }^{2}$ Department of Sociology, Institute of Social Sciences, Ege University, İzmir, Turkey

${ }^{3}$ Department of Parasitology, Ege University Faculty of Medicine, İzmir, Turkey

\section{ABSTRACT}

Objective: The well-known and common infestation caused by Pediculus humanus capitis is an important public health and a social issue in many communities in the world. The aim of this study was to compare the head louse infestation rate in two schools having pupils from different socio-economic levels in the city center of Izmir.

Methods: The pupils aged between 6 and 11 years, were screened for the presence of eggs and nymph/adult lice using a fine-tooth head louse comb.

Results: A total of 88 and 126 pupils from the schools with low and medium socio-economic level were screened and 24 (27.2\%) and 5 (3.96\%) of them were found to be positive for head lice, respectively. Overall, the infestation rate among girls was 3.14 times higher than in boys.

Conclusion: Head louse infestation is a significant public health problem among primary schools. Increasing the knowledge about pediculosis and self-hygiene would be helpful in successfully reducing head louse infestation in the school setting. School authorities must encourage the parents to look for head lice routinely and a "school nurse" system is needed for effective head louse control in the schools. (Turkiye Parazitol Derg 2014; 38: 32-6)

Key Words: Pediculus capitis, socioeconomic level, Turkey

Received: 18.11 .2013

Accepted: 25.12 .2013

\section{ÖZET}

Amaç: Pediculus humanus capitis kaynaklı enfestasyonlar dünya çapında yaygın olan ciddi bir halk sağlığı sorundur. Bu çalışmanın amacı İzmir de farklı sosyo-ekonomik düzeyde olan iki okulda, öğrencilerin baş biti enfestasyon oranlarını belirlemektir.

Yöntemler: 6 ve 11 yaş arası öğrenciler ince dişli bit tarakları kullanılarak baş bitinin (yumurta ve nimf/ergin) bulunması açısından incelenmiştir. Bulgular: Sosyo-ekonomik durumu düşük ve orta düzeyde olan okullardan toplamda 88 ve 127 öğrenci taranmıştır. Düşük seviyedeki okulda baş biti enfestasyon oranı $24(\% 27,2)$ ve orta düzeydeki okulda $5(\% 3,96)$ olduğu gözlenmiştir. Genel olarak kızlar arasındaki enfestasyon oranının, erkeklere oranla 3,14 kat daha fazla olduğu saptanmıştır.

Sonuç: Baş biti enfestasyonu ilköğretim okulları arasında gözlenen cidi bir halk sağlığı sorunudur. Pedikulosis ve kişisel hijyen konusunda bilincin artması okullarda bit enfestasyonunun azaltılmasında etkili olacaktır. Okul yönetiminin aileleri öğrencilerin saçlarını düzenli olarak kontrol etmesi konusunda teşvik etmesi ve okullara "Okul Hemşiresi" sisteminin getirilmesi baş biti kontrolünde etkili olacaktır.

(Turkiye Parazitol Derg 2014; 38: 32-6)

Anahtar Sözcükler: Pediculus capitis, sosyo-ekonomik düzey, Türkiye

Geliş Tarihi: 18.11.2013

Kabul Tarihi: 25.12 .2013

Address for Correspondence / Yazışma Adresi: Mehmet Karakuş, Department of Biology, Faculty of Medicine, Ege University, İzmir, Turkey. Phone: +90 2323394345 E-mail: mehmetk1986@yahoo.com DOI:10.5152/tpd.2014.3447

CCopyright 2014 Turkish Society for Parasitology - Available online at www.tparazitolderg.org

CTelif hakkı 2014 Türkiye Parazitoloji Derneği - Makale metnine www.tparazitolderg.org web sayfasından ulaşılabilir. 


\section{INTRODUCTION}

Pediculosis, also known as head louse infestation, is caused by Pediculus humanus capitis (De Geer, 1778), (Anoplura: Pediculidae), an obligate ectoparasite of man found on the hair and scalp (1). Head lice lay eggs on the hair shaft, close to the scalp, where the temperature is optimal for the development of the embryo (2). Because, P. h. capitis belongs to the hemimetabolous group of insects, there are little differences between adult and nymphal stages, however all of them are hematophagous. Usually it takes approximately seven days for the development of nymphs to adults (1,3-5). Pediculosis is often causes a socially undesirable condition accompanied by social stigma (6).

Many studies have conducted in Turkey comparing the social status and rate of pediculosis in different cities. These studies showed that the average, minimum and maximum infestation rates are $10.16 \%, 0.54 \%$ and $29.4 \%$, respectively (Table 1) (7-37). In this study, we aimed to compare the head louse infestation rates in two socio-economically different schools located in the city center of Izmir.

\section{METHODS}

Two primary schools located in the center of Izmir have been selected as representatives of low and medium socio-economic status. Permission was obtained from the Izmir Branch of the Ministry of Education for screening the pupils for head lice in these two schools.

Totally, 214 pupils (88 and 126 from the first and second school, respectively) at ages between 6 and 11 years were screened for the presence of eggs/nits and nymph/adult lice using a special

Table 1. Previous researches conducted in different regions of Turkey

\begin{tabular}{|c|c|c|c|c|c|}
\hline Author(s) & Year & City & Girl (\%) & Boy (\%) & Total (\%) \\
\hline Saygı et al. (7) & 1990 & Sivas & 13.3 & 1.3 & 7.3 \\
\hline Kişioğlu et al. (8) & 1991 & Kayseri & 20.4 & 2 & 3.5 \\
\hline Öztürkcan et al. (9) & 1991 & Sivas & 9.8 & 0 & 3.6 \\
\hline Yücel et al. (10) & 1994 & İstanbul & 30.39 & 6.9 & 18.05 \\
\hline Illhan et al. (11) & 1994 & İzmir/Karşıyaka & 9.3 & 2.3 & 5.6 \\
\hline Payzın F. (12) & 1995 & Sakarya & 54 & 17.2 & 34.1 \\
\hline Özcan et al. (13) & 1996 & Malatya & 1.3 & 0 & 1.3 \\
\hline Üner et al. (14) & 1997 & İzmir/Karşıyaka & * & * & 8.57 \\
\hline Karaman et al. (15) & 1997 & Aydın & 32.11 & 9.44 & 20.08 \\
\hline Yazar et al. (16) & 1997 & İzmir/Kemalpaşa & 29.9 & 4.9 & 16.4 \\
\hline Polat et al. (17) & 1999 & İstanbul/Silivri & 27.6 & 3.12 & 14.2 \\
\hline Orhan et al. (18) & 1999 & İzmir/Narlıdere & 36.7 & 9.8 & 23.3 \\
\hline İnceboz et al. (19) & 2000 & İzmir/Bornova & 12.34 & 1.45 & 6.71 \\
\hline Güleç et al. (20) & 2000 & Ankara & 9.1 & 1.8 & 5.2 \\
\hline Akısü et al. (21) & 2002 & İzmir/Narlıdere & 50.8 & 3.4 & 27.4 \\
\hline Kokturk et al. (22) & 2003 & Mersin & 13.3 & 1.1 & 6.8 \\
\hline Karataş et al. (23) & 2004 & Aydın & 19.6 & 2.2 & 10.6 \\
\hline Daldal et al. (24) & 2004 & Malatya & 2.12 & 0 & 1.25 \\
\hline Polat et al. (25) & 2004 & Sivas & 1.1 & 0 & 0.54 \\
\hline Oktun et al. (26) & 2005 & Edirne & 10.3 & 0.9 & 5.4 \\
\hline Akısü et al. (27) & 2005 & İzmir & 31.2 & 2.5 & 16.6 \\
\hline Oflaz, M. (28) & 2006 & Konya & 6.45 & 0.78 & 3.65 \\
\hline Çiftçi et al. (29) & 2006 & Afyon & 1.5 & 0.9 & 1.2 \\
\hline Noyan et al. (30) & 2006 & İzmir/Konak & 55 & 0 & 29.4 \\
\hline Oğuzkaya et al. (31) & 2006 & Kayseri & 16.4 & 2.1 & 9.2 \\
\hline Özçelik et al. (32) & 2006 & Sivas & 20.27 & 1.92 & 9.49 \\
\hline Dursun et al. (33) & 2009 & Van/Erciş & 23 & 3.3 & 9.5 \\
\hline Çetinkaya et al. (34) & 2010 & Kayseri/Hacılar & 21.5 & 1.4 & 10.9 \\
\hline Akkaş et al. (35) & 2011 & Iğdır & 22.9 & 3.2 & 13.1 \\
\hline Değerli et al. (36) & 2012 & Sivas & 12.9 & 0.2 & 6 \\
\hline Değerli et al. (37) & 2013 & Sivas & 13.7 & 1.1 & 10.2 \\
\hline
\end{tabular}


head louse comb. Combs were metal pin comb with an angled nylon grip and stainless steel pins are $31 \mathrm{~mm}$ long. Before combing, the pupils were informed about louse infestation and self-hygiene by a power point presentation. Each pupil has been examined alone in a separate room. Collected lice were examined under a stereo-microscope for determining the developmental stage of the head lice.

\section{RESULTS}

A total of 88 pupils from the first school with the low socio-economic level were screened and 24 (27.2\%) of them were found to be positive for head lice. Seventeen out of 31 girls (54.83\%) and 7 out of 57 boys (17.2\%) were positive for head lice (Table 2). Overall, 157 head lice were collected from 24 students; $47 \%$ of them were nymphs while $53 \%$ were adult lice.

A total of 126 pupils from the second school, with a low socio-economic level, were screened and 5 (3.96\%) of them were positive for head lice. Sixty-eight girls and 58 boys were combed and only 5 girls (7.35\%) were infested with head lice, while none of the boys was infested with lice. The overall prevalence in the second school was 3.96\% (5/126) (Table 2). In this school, 8 head lice were collected from 5 pupils and 6 of them were nymphs and 2 adults. No statistical differences were found regarding the age group of the 6-11-years old children, examined in the present study.

\section{DISCUSSION}

Head louse infestation is a public health problem even in welldeveloped countries. There are differences in the prevalence of head louse infestation between populations with different socio-economic levels, and many studies have stressed this point. The present study too was conducted to detect head louse infestation rates among pupils from two schools with different socio-economic levels.

Previous studies on head louse infestation, which were mostly performed among school children in Turkey, showed an average infestation rate of $10.16 \%$, where the minimum infestation rate reported was $0.54 \%$ and the maximum $29.4 \%$. In all 31 studies, girls showed a higher infestation rate than boys, i.e., $19.23 \%$ and $2.9 \%$, respectively. Accordingly, girls were in average 6.63 times more infested than boys (Table 1).

Earlier studies conducted in Turkey showed that the socio-economic differences have an effect on the rate of pediculosis capi-

Table 2. Infestation rate of the students in both schools

\begin{tabular}{|l|c|c|c|c|}
\hline \multicolumn{2}{|c|}{} & \multicolumn{1}{c|}{$\begin{array}{c}\text { 1st Primary School } \\
\text { (low socioeconomic } \\
\text { level) }\end{array}$} & $\begin{array}{c}\text { 2nd Primary School } \\
\text { (intermadiate } \\
\text { socioeconomic level) }\end{array}$ \\
\hline & $\begin{array}{c}\text { Screened } \\
\mathbf{n}\end{array}$ & $\begin{array}{c}\text { Infested } \\
\mathbf{n}(\%)\end{array}$ & $\begin{array}{c}\text { Screened } \\
\mathbf{n}\end{array}$ & $\begin{array}{c}\text { Infested } \\
\mathbf{n}(\%)\end{array}$ \\
\hline Boy & 57 & $7(12.28)$ & 68 & 0 \\
\hline Girl & 31 & $17(54.83)$ & 58 & $5(8.62)$ \\
\hline Total & 88 & $24(27.27)$ & 126 & $5(3.96)$ \\
\hline
\end{tabular}

tis (33). Çetinkaya et al. showed a correlation between family income and infestation rate. In another study, economically underdeveloped areas had a higher infestation rate than economically developed areas (38). In a study comparing the head louse infestation rates among four socio-economically different schools, the researchers found statistically significant differences between low (6.34\%) and high (0.6\%) socio-economic level schools (28). Aktas et al. separated the schools into three groups according to their socio-economic level. The first one had a high socio-economic level and $3.9 \%$ of the pupils were infested with head lice. The second school had a medium socio-economic level and $15.4 \%$ of the children were infested, while in the third group with a low socio-economic status the infestation rate was $22 \%$ (35). Previous studies also showed that the prevalence increased with decreasing total income levels in the family (16, $21,34)$. In this study, we also found a positive relationship between socio-economic status and head louse infestation. The prevalence of $P$. $h$. capitis was significantly lower $(p<0.0001)$ in the first school with a low socio-economic status.

Personal hygiene is also an important factor for head louse infestations and this is usually related to the educational level of the family and this was shown to be the case in previous studies done in Turkey. High infestation rates were found in children belonging to low educated families $(20,23,26,28,33,39-43)$. In Turkey too, mostly mothers take care of their children, and therefore their educational level and economic status has proven to be a significant factor on prevalence of head louse infestation (33). Though we did not used a questionnaire to interview the pupils in the present study, a general information about the socio-economic status of the children was obtained from the head-master of the schools.

Almost in all previous studies, the percentage of girls with pediculosis capitis was significantly higher than boys (6.63 times higher in average) (7-37). In the present study, we found that girls has $3.14(7 / 22)$ times higher infestation rate than boys, which could be explained with the fact that in general girls have longer hair and they can more easily infest each other.

\section{CONCLUSION}

In conclusion, head louse infestations may be regarded as a significant public health problem among primary schools and dormitories. Thus, the necessary education on hygiene should be given also to these school-age children. Increasing our knowledge of pediculosis may be helpful in successfully reducing head louse infestation in a school setting. School authorities must encourage the parents to look for lice routinely and a "school nurse" system is needed for an effective head louse control in the schools.

Ethics Committee Approval: The necessary permit from Izmir Branch of Ministry of Education was taken by Alsancak Protection and Adornment Association.

Informed Consent: The informed consent forms were taken from their teachers with the permission of student's family.

Peer-review: Externally peer-reviewed. 
Author Contributions: Concept - Y.Ö. S.Ö.T, M.K.; Design Y.Ö., S.Ö.T.; Supervision - Y.Ö.; Funding - M.K., A.A.; Materials Y.Ö., S.Ö.T.; Data Collection and/or Processing - M.K., A.A.; Analysis and/or Interpretation - M.K., A.A. Y.Ö.; Literature Review - M.K., A.A.; Writing - M.K., Y.Ö., S.Ö.T; Critical Review - A.A., S.T.Ö.

Acknowledgements: We would like to thank the Alsancak Protection and Adornment Association for taking the necessary permits and giving the appropriate education on hygiene to the pupils. The authors also wish to thank Dr. Kim Larsen for kindly providing the head louse combs.

Conflict of Interest: No conflict of interest was declared by the authors.

Financial Disclosure: The authors declared that this study has received no financial support.

Etik Komite Onayı: Bu çalışma için gerekli etik kurul izinleri İzmir Miili Eğitim Müdürlüğü ve Alsancak Güzelleştirme Derneği tarafından alınmıştır.

Hasta Onamı: Bilgilendirilmiş onam formları öğrencilerin aileleri ve öğretmenlerinin izni ile alınmıştır.

Hakem değerlendirmesi: Dış bağımsız.

Yazar Katkıları: Fikir - Y.Ö. S.Ö.T, M.K.; Tasarım - Y.Ö., S.Ö.T.; Denetleme - Y.Ö.; Kaynaklar - M.K., A.A.; Malzemeler - Y.Ö., S.Ö.T..; Veri toplanması ve/veya işlemesi - M.K., A.A ; Analiz ve/ veya yorum - M.K., A.A. Y.Ö.; Literatür taraması - M.K., A.A.; Yazıyı yazan - M.K., Y.Ö., S.Ö.T; Eleştirel Inceleme - A.A., S.T.Ö.

Çıkar Çatışması: Yazarlar çıkar çatışması bildirmemişlerdir.

Finansal Destek: Yazarlar bu çalışma için finansal destek almadıklarını beyan etmişlerdir.

\section{REFERENCES}

1. Gholamnia Shirvani Z, Amin Shokravi F, Ardestani MS. Evaluation of a Health Education Program for Head Lice Infestation in Female Primary School Students in Chabahar City, Iran: Arch Iran Med. 2013; 16: 42-5.

2. Wilson BB, Weary PE. Lice (Pediculosis). Mandell GL, Douglas RG, Bennett JE, editors. Principles and Practice of Infectious Diseases. Third Edition. 1990. p. 2163-5.

3. Saygı G. Temel Tıbbi Parazitoloji. Second Edition. Sivas: Esnaf Ofset Matbaası; 2002.

4. Brannon H. The Life Cycle, Symptoms, and Spread of Head Lice From Heather Brannon, MD, former About.com Guide Updated April 09, 2008

5. Burgess I. Current treatments for pediculosis capitis. Curr Opin Infect Dis 2009; 22: 131-6. [CrossRef]

6. Kurt O, Tabak T, Kavur H, Muslu H, Limoncu E, Bilaç C, et al. Comparison of Two Combs in the Detection of Head Lice in School Children. Türkiye Parazitol Derg 2009; 33: 50-3.

7. Saygı G, Özçelik S, Temizkan N, Erandaç M. Sivas'ta üç ilkokulun öğrencileri arasında Pediculus humanus capitis yaygınlığının araştırılması. Türkiye Parazitol Derg 1990; 14: 75-83.

8. Kişioğlu AN, Gökmerdan A. Kayseri Ayşe Baldöktü Çıraklık Eğitim Merkezinde Pediculus humanus capitis'in yaygınlığının araştırılması. Türkiye Parazitol Derg 1995; 19: 531-4.
9. Öztürkcan S, Özçelik S, Saygı G, Özçelik S. Sivas çocuk yuvasındaki çocuklar arasında skabies ve Pediculus humanus sıklığının araştıııması. Türkiye Parazitol Derg 1996; 17: 42-6.

10. Yücel A, Çalışır B, Polat $E$, Aslan $M$, Ünver AC. İstanbul'un 6 ilçesinde ilkokul çocuklarında bitlenme sorununun araştırıması. Türkiye Parazitol Derg 1994; 8: 492-7.

11. Ilhan F, Budak S. İmir-Karşıyaka'da bir ortaokul ve dört ilkokulun öğrencileri arasında pediculus humanus capitis'in yaygınlığının araştıııması ve iki yıl önce yapılan tarama sonuçları ile karşılaştıııması. Türkiye Parazitol Derg 1994; 18: 485-91.

12. Payzın F. Sakarya söğütlü sağlık ocağı bölgesindeki ilkokul birinci sınıflarda baş biti prevalansı. Türkiye Klinikleri J Med Sci 1995; 15 : $57-60$

13. Özcan A, Doğan G, Şenol M, Yakıncı C, Şahin S, Yoloğlu S. Malatya'da ilkokul öğrencilerinde pedikülozis kapitis ve skabies araştırması. Türkiye Parazitol Derg 1996; 20: 61-5.

14. Üner A, Özensoy S, Tappeh KH, Akar Ş, Gürüz Y, Kundakçı Ü. İzmir'in Karşıyaka ilçesi ilkokul çocuklarında bağırsak parazitleri ve baş biti araştırılması. Türkiye Parazitol Derg 1997; 21: 39-43.

15. Can Karaman G, Bozkurt E, Şendur N, Başak O. Aydın ilinde ilkokul çağındaki çocuklarda pedikülozis kapitis sıklığı. T Klin Dermatoloji 1999; 9: 18-21.

16. Yazar S, Sülar C, Sevgi I, Akgündüz N, Çınar MC, Kitapçıoğlu G, Altıntaş N. Kemalpaşa'da okullardaki Pediculus humanus capitis yaygınlığının araştırılması. Türkiye Parazitol Derg 1999; 23: 273-8.

17. Polat E, Çalışır B, Aslan M, İsenkul R, Kutlubay Z, Özdemir H, Bilgehan H, Sağlam M, Şengül H, Demir M, Güney G, Aksın NE, Altaş K, D Akıncı T, H Aydemir E. Silivri ilçesi ve köylerindeki ilköğretim okullarında bitlenme durumu. Türkiye Parazitol Derg 2000; 24: 373-5.

18. Orhan V, Akısü Ç, Aksoy Ü. İzmir Narlıdere'de sosyoekonomik farklılığı olan çevre okullarında Pediculus humanus capitis yaygınlığı. Türkiye Parazitol Derg 2000; 24: 264-7.

19. Inceboz T, Alyanak Ş, Üner A, Bornova'daki okullarda Pediculus humanus capitis yaygınlığının araştırılması. Türkiye Parazitol Derg 2000; 24: 376-9.

20. Güleç M, Kır T, Tekbaş ÖF, Ceylan S, Hasde M. Çiçekli Illköğretim Okulu öğrencilerinde Pediculus humanus capitis enfestasyonu prevalansının ve buna etki eden faktörlerin araştıııması. Türk Hij Den Biyol Derg 2000; 57: 13-8.

21. Akısü Ç, Sarı B, Aksoy Ü, Özkoç S, Öztürk S. Narlıdere'deki bir ilköğretim okulunda Pediculus humanus capitis yaygınlığının araştırılması ve önceki sonuçlarla karşılaştııılması. Türkiye Parazitol Derg 2003; 27: 45-8

22. Kokturk A, Baz K, Bugdayci R, Sasmaz T, Tursen U, Kaya TI, Ikizoglu $\mathrm{G}$. The prevalence of pediculosis capitis in schoolchildren in Mersin, Turkey. Int J Dermatol 2003; 42: 694-8. [CrossRef]

23. Karataş E, Sari C, Ertabaklar H, Okyay P, Ertuğ S. Aydın Illinde Üç illköğretim Okulunda Pediculus capitis Prevalansı. Türkiye Parazitol Derg 2003; 28: 38-41.

24. Daldal N, Atambay M, Aycan ÖM, Karaman Ü, Ersoy Y. Malatya'da iki Ilköğretim Okulu Çocuklarında Pediculus capitis Yaygınlığının Araştııılması. İnönü Üniversitesi Tıp Fakültesi Dergisi 2004; 11: 11-3.

25. Polat ZA, Saygi G. Bir İlköğretim Okulu Öğrencilerinin Bir Yıl Arayla Ektoparazitler Yönünden Yeniden Taranması. Türkiye Parazitol Derg 2004; 28: 110-2.

26. Tatman Otkun M, Gürcan Ş, .zer B, Ertem A, Şakru N, Oktun M. Edirne merkez ilk.ğretim okulları öğrencilerinde pedikulus humanus kapitis ve tinea kapitis sıklığı. Trakya Üniv Tıp Fak Derg, 2005; 22: 82-7.

27. Akisu C, Aksoy U, Delibas SB, Ozkoc S, Sahin S. The prevalence of head lice infestation in school children in Izmir, Turkey. Pediatr Dermatol 2005; 22: 372-3. [CrossRef]

28. Oflaz M. Konya'da sosyo-ekonomik yönden farklı olan iki bölgedeki ilköğretim okullarındaki çocuklarda Pediculus humanus capitis 
yaygınlığı Selçuk Üniv., Sağlık Bil. Enst. Parazitoloji (Vet) Anabilim Dalı Yüksek Lisans Tezi, 2006

29. Ciftci IH, Karaca S, Dogru O, Cetinkaya Z, Kulac M. Prevalence of pediculosis and scabies in preschool nursery children of Afyon, Turkey. Korean J Parasitol 2006; 44: 95-8. [CrossRef]

30. Noyan E, Demir V. Investigation of pediculosis carried out as the special study module No. 74, a part of Ege University Medical Faculty's educational program. Türkiye Parazitol Derg, 2006; 30: 32-4.

31. Oğuzkaya Artan M, Baykan Z, Koç AN. Kayseri ili kırsalındaki sekiz ilköğretim okulunda Pediculus capitis prevalansı. Türkiye Parazitol Derg 2006; 30: 112-4.

32. Özçelik S, Değerli S, Aslan A. Sivas Alahacı köyü ilköğretim okulu öğrencilerinde Pediculus yaygınlığının araştırılması. Türkiye Parazitol Derg 2006; 30: 184-6.

33. Dursun N, Taş Cengiz Z. Van'ın Erciş Illçesinde Baş Bitinin Yayılışı. Türkiye Parazitol Derg 2010; 34: 45-9.

34. Cetinkaya U, Hamamcı B, Delice S, Ercal BD, Gücüyetmez S, Yazar S, et al. The Prevalence of Pediculus humanus capitis in Two Primary Schools of Hacılar, Kayseri. Turkiye Parazitol Derg 2011; 35: 151-3. [CrossRef]

35. Akkaş Ö, Taş Cengiş Z. Iğdır ilinde bazı ilköğretim okullarında baş bitinin yaygınlığı Türkiye Parazitol Derg, 2011; 35: 199-203

36. Değerli S, Malatyali E, Çeliksöz A, Özçelik S, Mumcuoğlu KY. The Prevalence of Pediculus humanus capitis and the Coexistence of Intestinal Parasites in Young Children in Boarding Schools in Sivas,
Turkey Pediatric Dermatology Volume 29, Issue 4, pages 426-429, July/August 2012. [CrossRef]

37. Değerli S, Malatyalı E, Mumcuoğlu K. Head Lice Prevalence and Associated Factors in Two Boarding Schools in Sivas. Turkiye Parazitol Derg 2013; 37: 32-5. [CrossRef]

38. Rodina M. AL-Shawa Pediculus capitisi infestation according to sex and social factors in Gaza Governorate The Islamic University Journal (Series of Natural Studies and Engineering) 2008; 16: 75-83.

39. Atambay M, Karaman Ö, Karaman Ü, Aycan Ö, Yoloğlu S, Daldal N. Akşemseddin işitme engelliler ilköğretim okulu öğrencilerinde bağırsak parazitleri ve baş biti görülme sıklığı. Türkiye Parazitol Derg 2007; 31: 62-5

40. Gholamnia Shirvani Z, Amin Shokravi F, Ardestani MS. Evaluation of a health education program for head lice infestation in female primary school students in Chabahar City, Iran. Arch Iran Med 2013; 16: 42-5.

41. Oğuzkaya Artan M, Baykan Z, Koç AN. Kayseri ili kırsalındaki sekiz ilköğretim okulunda Pediculus capitis prevalansı. Turkiye Parazitol Derg 2006; 30: 112-4.

42. Mahmud S, Pappas G, Hadden WC. Prevalence of head lice and hygiene practices among women over twelve years of age in Sindh, Balochistan, and North West Frontier Province: National Health Survey of Pakistan, 1990-1994. Parasites \& Vectors 2011 4:11.

43. Rukke BA, Birkemoe T, Soleng A, Lindstedt HH, Ottesen P. Head Lice in Norwegian Households: Actions Taken, Costs and Knowledge. 2012: PLoS ONE 7(2). [CrossRef] 